\title{
MUSICAL INTERPRETATION: \\ CASE STUDY IN MUSICAL INSTRUMENT PRACTICE LEARNING VOCATIONAL HIGH SCHOOL
}

\author{
Ayu Niza Machfauzia \\ Universitas Negeri Yogyakarta \\ ayu@uny.ac.id \\ Suminto A. Sayuti \\ Universitas Negeri Yogyakarta \\ suminto@yahoo.com \\ Djohan \\ ISI Yogyakarta \\ djohan.djohan@yahoo.com
}

\begin{abstract}
This study was intended to reveal: (1) the dimensions of musical interpretation taught; (2) the strategy used by teachers to introduce musical interpretation in instrument practice class; and (3) teacher's ability or competence to teach musical interpretation. This research is case study, with the subjects were 12 teachers responsible for instrument practice class. They were selected using purposive sampling method. The data collection method used were in-depth interviews, passive participation observation, documentation and focus group discussion (FGD). The instrument of study was the researcher herself. Data validity was conduct triangulation by reviewing data acquired from a source. All data then were analyzed using interactive model which included data reduction, data presentation, and conclusion/verification. The results show that: (1) the dimensions of musical interpretation taught in every instrument practice class, were only dimensions of knowledge; (2) the strategy used by teachers when teaching musical interpretation was a direct strategy, teachercentered learning approach, and used individual approach; and (3) teachers' competence in teaching musical interpretation must be improved, both pedagogical and professional competences.
\end{abstract}

Keywords: musical interpretation, teaching, teacher competence 


\section{INTRODUCTION}

Vocational education is a type of midlevel education which aims to prepare students before applying for work. Vocational education system provides knowledge and skills that are needed in order to ease their experience in the workplace. It is related to the way the teacher teach or embed values in certain work areas.

As we know it, vocational education in Indonesia has two targets preparing students before entering the workplace and advancing them to higher education (Andini, 2007), Meanwhile, the concept of vocational education today tends to promote life skills education paradigm (Abadi, 2011, p. 1). Life skills are needed because vocational education is expected to provide proper skills for the graduates before facing the outside world and be able to solve problems encountered in real life. Therefore, students in vocational school need to be equipped with knowledge, skills, and life skills that can be used and useful in their workplace, as well as musical expertise.

Musical skill is one of 12 vocational disciplines which has been established within the framework of international curriculum (Rauner, 2009, p. 1447), and also one of the skill competences in vocational education skills spectrum (SK Ditjen Mandikdasmen No. $251 / \mathrm{C} / \mathrm{kep} / \mathrm{mn} / 2008$ ). In the field of musical skills, students need to be equipped with the knowledge of musical theories and musical instruments performance skills, including interpreting a piece of music, either artistic or non-artistic piece of music, before entering the workplace, especially as a player.

SMK Negeri 2 Kasihan Bantul Yogyakarta (formerly known as Music High School) is the only vocational high school which a music program and remains consistent with the basic skill areas of Western art music. This school is one of the most desired vocational school by junior high graduates. This is evident from the increasing number of students accepted each year at the school within the past three years.

As the only vocational school that provides musical programme with Western art influences such as Baroque, Renaissance, Classical, and Romantic, the school administration must prepare its students so that they are wellprepared for future workforce competition. Many musical and life skills are taught in the school so that their graduates may compete and dominate the existing labour market.

Most of the time, graduates of SMK Negeri 2 Kasihan Bantul were accepted in many sectors. It is proved tha until 2018, a total of $75 \%$ of the Twilite Orchestra musicians are alumni of SMK Negeri 2 Kasihan Bantul (Ghozali, 2018). Prevoiusly, in 2010/2011, 24 alumni of this school became part of Indonesian Police Headquarters Musical Corps in Jakarta, while in 2012 about 22 alumni were accepted to the Indonesian Air Force based in Adisutjipto Airport, Yogyakarta.

Furthermore, the alumni of SMK Negeri 2 Kasihan Bantul who work as a teacher in music institutions, such as Purwa Caraka Music School, are numbered around 27 people and spread across various cities in Indonesia. This indicates that the school graduates are much absorbed as both a solo musician or group, and also as a teacher in music class institutions with various kinds of musical instruments that they mastered.

In vocational schools that has a music program like SMK Negeri 2 Kasihan Bantul, the learning process, especially on the subjects of major instrument practice, ideally the ratio between teachers and students is 1:1. This means that the learning process required a faceto-face ratio of 1 teacher to 1 student (private). With such an ideal condition, it is expected that the teacher can give a thorough teaching and a concrete example in applying the techniques of playing a musical instrument which includes attitudes, skills, and interpretation when performing a musical work in harmony with the characteristics of the musical work being played.

When playing a piece of music, especially works of Western art music, students need to be aware that many elements are contained in the music, so students must analyze each element in the music in order to know what the comoser's intention is. After analyzing it, the student is required to communicate any of these elements to the audience. The only way to communicate it is to use a method that is interpretation. Interpretation itself is an understanding or translation of the symbols and elements of music contained in a score.

Furthermore, in order to interpret a piece of music, students should also learn every element of music featured in the score, because we need to realize that in music itself there are 
many elements of music (Duckworth, 2010, p. $\mathrm{xxii}$ ) in addition to the fundamental elements it has. If students can interpret or understand a piece of music properly, they are also expected to communicate the work to the audience properly. This is because the interpretation is also associated with communication. Therefore, students also need to know and understand the structure and analysis of musical form.

According to Hermeren (2001, p. 13), the purposes of interpretation in music, among others, are to know what the composer wishes, to express and communicate feelings, and to describe the historical, social, and psychological conditions for the creation of works that are about to be interpreted. Interpreting a piece of music, especially the artistic music, is necessary in order to provide clarity to every tone that has been created by the composer, and clarity is produced in a musical performance. Therefore, musical interpretation is closely related to the musical performance.

A musician can be said to be a professional in the field of music if he has good skills (in terms of musical instrument playing techniques), and has the capability of understanding musical interpretation and be able to apply it when performing a piece of music. The statement was confirmed by Sloboda's opinion in Reid (2002, p. 104) which said, "a performer Might be a superb technician but lack of musical insight, and vice versa. An expert musician will be Able to balance technical finesse with interpretive understanding." Thus, to be an expert musician is not enough by having the skills to play instruments/singing alone, but also a good insight about music, so that there is a balance between the skills of playing instruments/singing and interpretive understanding.

In SMK Negeri 2 Kasihan Bantul, one of the objectives to be achieved in the process of learning is that the students can master the instrument practice well. They are expected to perform well, either solo or in groups. However, to realize the capabilities that are about to be achieved is not easy. This is because there are still barriers that need to be addressed, such as the students' lack of the ability to interpret a piece of music especially when performing it.

On the implementation of the instrument practice learning process, teachers tend to teach matters related to instrument playing techniques/singing techniques, while musical interpretation is not taught explicitly. This resulted in students who don't understand with musical interpretation learning. When playing a piece of music, especially works of western art music, students only play what is written in the score. This means that every element of music, including music history in and about the repertoire, is not well understood. In reality, the art of interpretation is not only to play what is written on the score track, but also make a possibility for students to create the elements contained in the score musically while informing it, and make it artistic.

Casals (Kitelinger, 2010, p. 1) stated that, "Without interpretation, it is just poor penand paper music". That is, if a music performer didn't user interpretation while performing a piece of music, the song will be felt as monotonous or "bland". To that end, a music performer needs to have knowledge of music, musical ability, sensitivity to music, and a good musical quality, in order to interpret a musical work properly. This is necessary because musical interpretation (Silverman, 2007, p. 101) is more than an aural photocopy of the score, and an act that brings the entire ability of a person which includes intellectual, social, cultural, artistic, physical, emotional, and personal into musical performance events. Another opinion related to musical interpretation is expressed by Kitelinger $(2010$, p. 2$)$ which is the process of discovering the meaning implied in the written symbols. As in linguistics, a music interpreter (teacher) exchanges these symbols in an agreed system of meaning (consensus), and it is paving the way for music to become a medium of communication.

From the opinions that have been described, it can be said that the musical interpretation is to recreate what has been written by the composer from a music presenter so that the music has an understood meaning and becomes an artistic sound. Therefore, musical interpretation should be taught in instrument practice learning. This is because musical interpretation is the understanding of a whole piece of music.

Based on the problems described above, the objectives of this study were (1) to reveal the dimensions of musical interpretation taught by teachers; (2) to know the strategies used by teachers in teaching musical interpretation in instrument practice learning; (3) to show the teachers' competence when teaching musical interpretation instrument practice learning. 


\section{Research Method}

This study uses case study qualitative approach. We use case study because we need to learn more about the individuals (teacher) in order to help them adapting well (Gerring, 2007 , p. 12). This study is also an empirical study which explores phenomena (Yin, 2009, p. 18) about musical interpretation learning that must be taught in instrument practice which includes knowledge, perception, and musical experience.

When conducting this case study, the researcher investigate and probe into a particular phenomenon (case) regarding how a teacher teach musical interpretation, and then the interpretation dimensions (knowledge perception, and experience) which are being taught by instrument practice teacher to $10^{\text {th }}$, $11^{\text {th }}$, and $12^{\text {th }}$ grade students of SMK Negeri 2 Kasihan Bantul Yogyakarta can be determined.

The study was conducted from August to December 2012. The data was collected at SMK Negeri 2 Kasihan Bantul, Yogyakarta. This is it is the only vocational school with a musical expertise area which consistently teaching western music learning, so it is interesting to study how instrument practice teachers teach musical interpretation which includes knowledge, perceptions, and experiences.

Teachers who administer instrument practice subjects are amounted to 12 people and determined purposively by adjusting it to the research objectives. Teachers become the subjects of this study because teachers play a major role in every educational system, including music education. Teachers will teach and impart knowledge about music to their students, including teaching musical interpretation. By teaching musical interpretation, students are expected to understand and know it so that they can apply it when performing western art music.

This case study was conducted in three phases, namely pre-field, in the field, and postfield. At the stage of pre-field, the researcher created a study permission for preliminary study as well as research, prepared interview manual, recording devices such as cameras, camcorders, and notebooks.

In the field, the researcher carried out further assessment of the place of study (SMK Negeri 2 Kasihan Bantul) for data collection. Because qualitative research methods put more emphasis on process rather than outcome, to meet the accurate results, the researcher see the whole process so this study puts the researcher as the main instrument in extracting and processing of the obtained data.

In the post-field phase, the researcher carried out a series of process of data analyses and interpretation of data that has been obtained previously. All data that has been analyzed is written in the form of a report.

Most of the data in this study are presented in form of words and sentences. Others are in form of pictures which were obtained via photography and video taping. On her case study, Yin (2009, p. 83) said that there are six sources which can be used to collect evidence and data for research purposes: documentation, records archive, interviews, field observation, participatory observation, and physical artefacts.

Pertaining to this study, data that were collected as evidence were obtained through the use of four different data collection techniques, namely (1) in-depth interviews; (2) observation; (3) documentation; and (4) a focused group discussion (FGD). Interviews were conducted face-to-face (Gillham, 2000, p. 62) to provide flexibility in communicating with the research subject, in this case the teachers who teach instrument practice: Drs. Gmr I (Clarinet and Saxophone); Brn Ari, S. Sn. (Trumpet); Drs. Stn, M. Pd. (Oboe); Sprj, M. Sn. (Guitar); Fd, M.A. (Violin); Brg Brt W, EP. (Cello); Fr gf. S. Pd. (Violin); Drs. Sdrt (Cons Bas); Utr, S. Sn. (Piano); Drs. Lg SMJ (vocals); and Dra. Yhn L.S. (Vocal). Interviews were conducted after the class was dismissed and resting time. The questions asked are not separated from the interview manual that has been prepared. However, it is possible that those questions are spontaneous but still inside the fringe of the studied issues.

Passive participant observation is an observation made directly to an object that is studied in a natural setting. In other words, researchers observe directly the ability of teachers, teachers' strategies, as well as the teachers' competence in teaching musical interpretation in instrument practice learning. While on observation, the researcher conducted a simple observation that consists of three elements (Gillham, 2000, p. 45), namely (1) to see what the teacher taught related to musical interpretation following instrument practice 
learning process which has been implemented by teachers according to a predetermined schedule; (2) to listen to what the teacher says; and (3) at any time, to ask the teachers to explain the questions that are asked. Data acquisitions by observation were noted and recorded in form of videos and photos.

Documentation is used to get data that are needed. Documents used in thi study are presented in form of written report and illustrations (Sugiyono, 2012, p. 82). Written documents provided here are instrument practice syllabi, while the illustrated ones are comprised of photos and videos which were taken during teaching process in school. Figure 1, 2, and 3 serve as the examples of instrument practice learning.

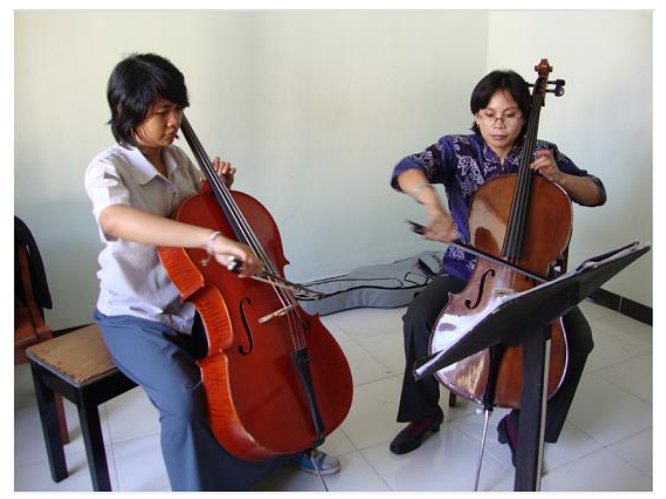

Figure 1. A Teacher Teaches a $9^{\text {th }}$ Grade Student How To Play Cello (Collection: Ayu,2012)

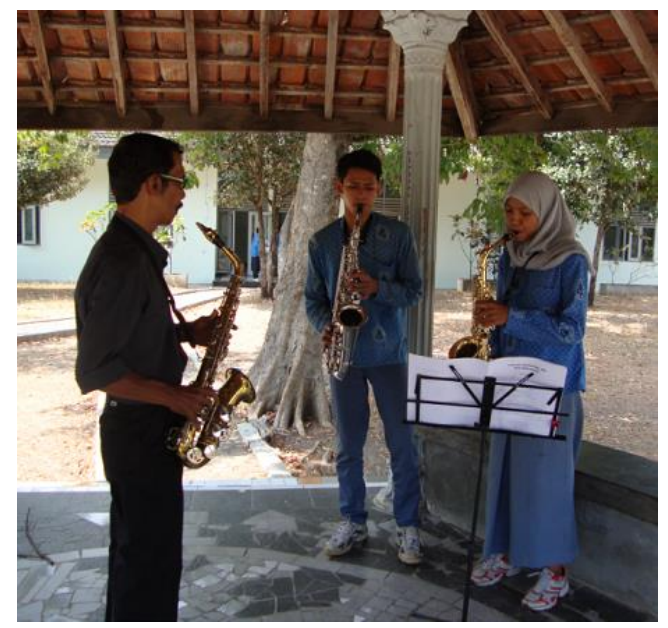

Figure 2. A Teacher is Pay Attention Student of Grade 12 in Playing Scales

(Collection: Ayu, 2012)

Data that have been obtained through interviews, observation, and further documentation is verified through focused group dis- cussion. FGD itself is a data collection activities by means of group discussion to discuss issues that have been determined, and is done in a systematic and purposeful way. FGD in this study was held on January 21, 2013 and attended by 4 teachers of instrument practice as research subjects, and is facilitated by one moderator and assisted by two people who helped record the course of the FGD. The discussion material in this FGD is related to instrument practice learning, especially musical interpretation learning.

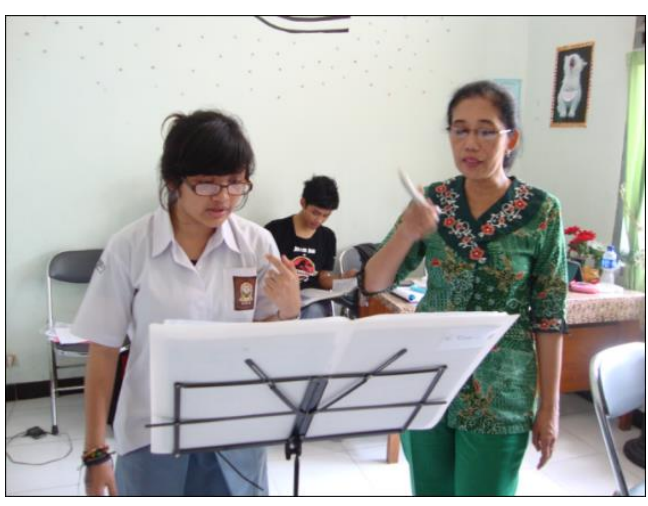

Figure 3. A teacher is Teaching Singing Techniques to a Student. (Collection: Ayu, 2012)

The data analysis consists of three stages: pre-field, in the field, and post-field. Pre-field data analysis is to analyze the results of preliminary studies, which are used to determine the focus of research. The results of preliminary studies indicate that when playing a piece of music, a student reading directly the scores of the song, while the teacher only directs how to read notation correctly. It seems that teachers only transfer knowledge to students. Whereas in playing a piece of music, especially artistic musical works, reading notation correctly is not enough, the interpretation of the score itself is also required. This is the focus of research.

In field analysis is performed interactively (Miles \& Huberman, 1994; Sugiyono, 2006) and carried out continuously until the data collection was complete. At the time of interview and observation, analyses of the answers and the observed phenomena are also conducted.

The components analyzing interactive model data (Miles \& Huberman, 1994, p. 10) used in this study consisted of 1) data reduc- 
tion, 2) data presentation, and 3) conclusion / verification. Data reduction is done by summarizing, taking basic and important data, and make categorization. The steps of data reduction (Lacey \& Luff, 2001; Patilima, 2011) were conducted in this study: transcription, data organization, recognition, and coding. After data reduction is done, the next step is to present the data. In this study, the data is presented in the form of narrative text. In addition, the data are also presented in tabular form.

In this study, data that related to strategies used by teachers, and teachers' competence in teaching musical interpretation are presented narratively, while data that related to the dimensions of musical interpretation are presented in tabular and narrative form.

The final step of this interactive model data analysis is conclusion. The study finds the weakness of teachers in the teaching musical interpretation. Their weakness is how lessdetailed the information given in class related to musical interpretation. Teachers teach playing musical instrument/singing techniques more than other techniques. Based on findings obtained in this study, an alternative strategy about western musical interpretation learning may be applied, which is comprised of five M's. They are learning (mempelajari), seeing (melihat), hearing (mendengarkan), comparing (membandingkan), and discussing and reflecting (mendiskusikan dan merefleksikan).

\section{Results and Explanation}

In instrument practice learning, musical interpretation is one of important aspects that need to be taught to students along with instrument practice technics. In learning process, students are not only equipped with the skills to play any instrument, but also equipped with the knowledge, and the ability to interpret a piece of music being played.

Developing interpretations of the music being played, according to Ford $(2011$, p. 2) is one of the most important and enjoyable aspects of music making. This is because interpretation can reflect the ideas and feelings of the player about the music which is being played. Thus, through interpretation, a player can communicate his emotional connection with the music being played. However, Ford (2011) also said that unfortunately many musicians and music teachers are generally more concentrated to notes and rhythm which are part of the framework of interpretation. This also happens instrument practice learning at SMK Negeri 2 Kasihan Bantul, especially in musical interpretation learning. In the learning process, the teacher concentrates more on notes, rhythm, music instrument performance techniques. This is proved by interviews described in another section. The dimensions of musical interpretation which are taught are limited to how to read notes and rhythm correctly. This activity is shown in Figure 4.

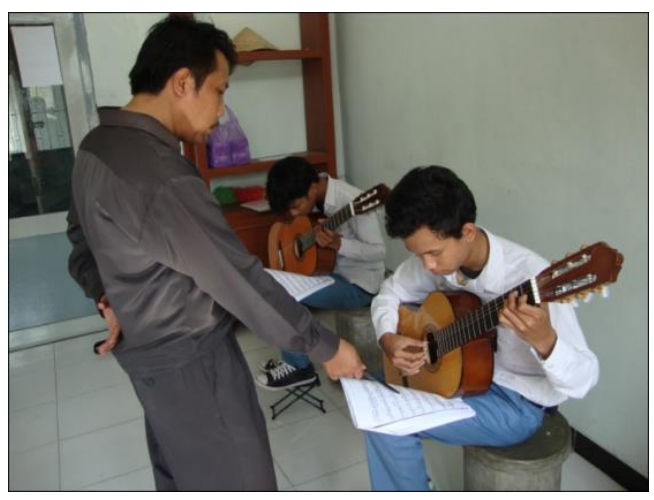

Figure 4. A Teacher Teaches How to Read Notes Correctly in a $12^{\text {th }}$ Grade Classroom. (Collection: Ayu, 2012)

In Figure 4, we can see that the teacher still guides his students to read notes on a musical sheet. This is done because the $12^{\text {th }}$ grade students are experiencing problems in reading notes. The same condition is also described on an interview with Sprj:

Anak-anak itu masih sulit bacanya...jadi masih perlu dituntun. Kalau engga ya..mereka mandeg ga praktik. Ga cuma baca not yang masih masalah, tapi juga baca ritmenya juga masalah. (Students have difficulties when reading notes, so they must be guided. If they are not guided, they would stuck and won't practice. Not only reading notes, they also can't read rhythms properly.) (Ptn).

Instrument practice learning such as in a guitar class goes on until the end of class. Sometimes, the teacher gives an example of musical performance that is being taught, then the students imitate what the teacher did. This activity is illustrated in Figure 5. 


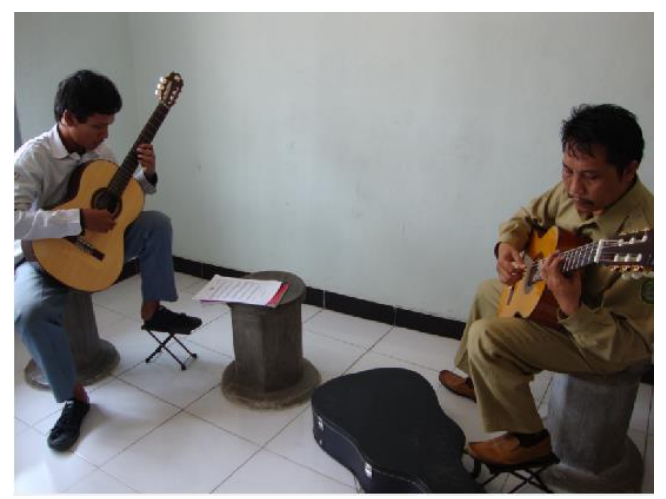

Figure 5. A Teacher Shows a $12^{\text {th }}$ Grade Student How to Play Music.

(Collection: Ayu, 2012)

In violin class, both $\mathrm{A}$ and $\mathrm{B}$ ( $\mathrm{A}$ is administered by Fr Gf, while B is by Fd), and cello class, the teachers are more focused to the playing techniques. This is in line with an interview with Fr Gf:

Dalam praktik instrumen itu yang penting adalah teknik permainan. Nek teknike wis dikuasai, sing liane gampang. (If the playing techniques are finally mastered, they can easily master other techniques). (Ptn).

The same thing is also said by $\mathrm{Fd}$ and $\mathrm{Brg} \mathrm{Brt} \mathrm{W}$ who added that playing techniques is one of the most important things to be taught in instrument practice.

Dalam praktik instrumen, teknik-teknik permainan menjadi pokok penting yang diajarkan, karena kalau siswa tekniknya bagus, maka dia bisa juga meng-interpretasikan karya musik yang dimainkan. (In instrument practice, the performance techniques are the important aspects that are taught, because if students know the techniques, they may interpret a song that they play.) (Ptn) (interview with Fd.).

Nek ngajari praktek sik penting ya teknik, etude dan lagu noo..Nek iso teknik, siswasiswa iso main dewe ora tergantung karo gurune. (When teaching practices, the most important things are techniques, etude, and song. If students know the techniques, they can play a song without assistance from their teacher). (Ptn) (interview with Brg Brt W).

Based on those interviews, we can conclude that technique is the main thing that mut be taught in instrument practice. According to $\mathrm{Fd}$, if students mastered the technique, they can interpret the piece of music being played. In order to interpret a musical work, playing technique is not enough, a performer needs to have the knowledge and skill labout musical interpretation itself. The learning process on playing techniques is illustrated in Figures 6 and 7.

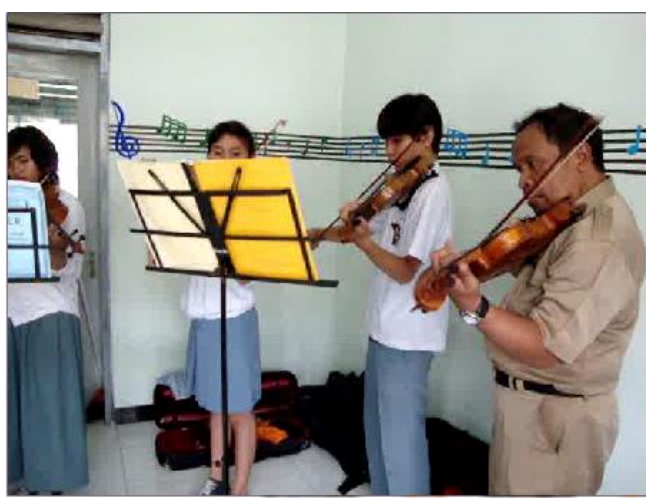

Figure 6. A Teacher Performs Bowing Technique with $12^{\text {th }}$ Grade Students. (Collection: Ayu, 2012)

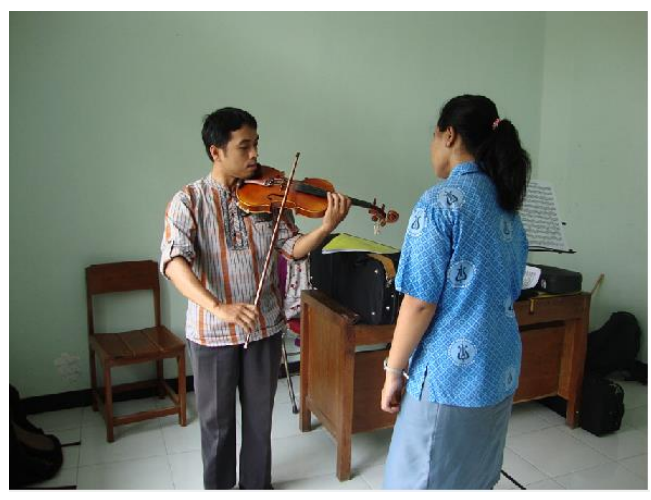

Figure 7. A Teacher Performs Fingering Technique with a $12^{\text {th }}$ Grade Student. (Collection: Ayu, 2012)

On Figure 6 in violin class A, we can see that the learning process is pretty classical, while in violin class B (Figure 7), the learning process is individual. Nevertheless, individual approach is also added in violin class A, especially when the teacher assessed every single student's technique. Like both violin classes, the same process also occurred in other class as told by Yhn L.S (vocal class A teacher):

Kelas X lebih ditekankan ke teknik, ya... pernafasan, intonasi, pengucapan, karena mereka kan baru pertaman kali belajar vokal ini. Selain itu, mereka juga harus 
banyak latihan membaca partitur. (Class $X$ is directed towards techniques... breathing flow, intonation, pronunciation, because they are first-timers in the vocal class. They also need to read more musical scores.) (Ptn).

From those classes, it can be explained that in the instrument practice learning process, teachers tend to emphasize things related to basic techniques of playing instruments and singing (breathing).

Meanwhile, one of interpretation frameworks that need to be taught is frasering (White, 2009), taught in saxophone and piano classes. In both classes, the students are wellmotivated to train themselves. When attending practice learning process, students can perform a song with ease without any guidance whatsoever. However, the teacher guides the students to play melodies in one phrase, known as frasering. An interview with the saxophone teacher (Gmr I) proves the statement above:

Siswa-siswa kelas XI ini jauh lebih termotivasi dalam praktik daripada siswasiswa kelas XII. Mereka sangat mandiri, sehingga saya tidak perlu lagi menuntun mereka membaca notasi. Saya tinggal mengajarkan frasering dan sedikit-sedikit saya ajarkan juga bagaimana menganalisis lagu. (The $11^{\text {th }}$ grade students are more motivated for practice rather than the $12^{\text {th }}$ grade ones. The $11^{\text {th }}$ grade students are more independent. I don't even need to guide them reading notes. I can just teach them frasering and slowly teaching how to analyze songs.) (Ptn).

The same thing also said by piano teacher (Utr) as told in an interview:

Mereka saya ajari bagaimana memainkan frasering, karena mereka sudah tidak masalah dalam membaca. Jadi perlu ditingkatkan lagi teknik-teknik per-mainannya,salah satunya bagaimana memainkan melodi dalam satu frase. (I taught them how to play frasering because they have no problems in reading. They need to improve their playing techniques, including how to play melodies in a phrase.) (Ptn).

The learning process of frasering in saxophone and piano practices class is illustrated in Figures 8 and 9.

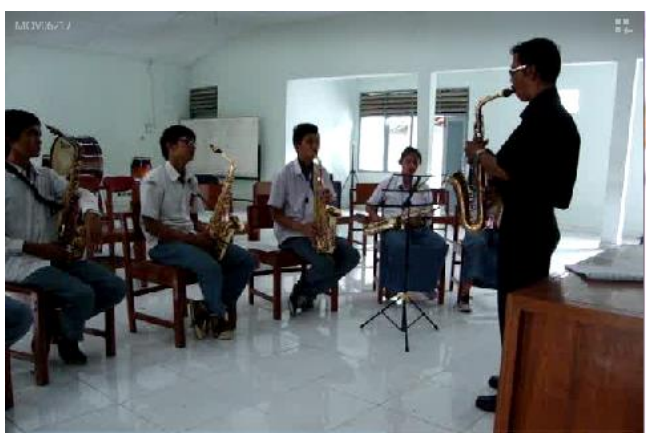

Figure 8. A Teacher Gives an Example on How to Play a Melody in One Phrase to $10^{\text {th }}$ Grade Students.

(Collection: Ayu, 2012)

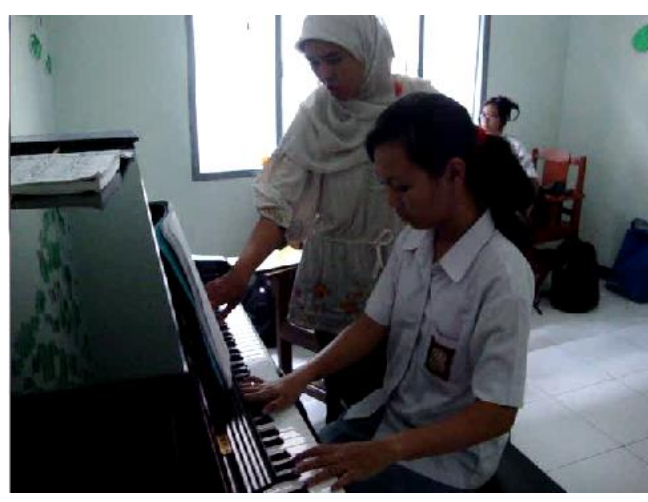

Figure 9. A Teacher Shows the $12^{\text {th }}$ Grade Students the Melodies that are Played in One Phrase. (Collection: Ауи, 2012)

Based on Figures 8 and 9, the teacher taught frasering to students that are already fluent when reading musical notes. Frasering I taught because if students could play melody in one phrase, they may interpret a song independently.

Regarding the learning strategy used by teachers to teach musical interpretation, every intrument practice teacher used various methods like imitation method, demonstration method, and drill method. Preaching method is used to explain things related to performance techniques. Imitation method is used to give an example to the students, and then they follow what the teacher did. Demonstration method is used to show an example of instrument performance performed by the teacher, while the drill method is used to help students playing some parts of the song that are considered difficult. With the application of drill method, students would not find any difficulties when performing a song in the future. 
The use of these methods in practice is collaborated with one another and adapted to a variety of factors such as the development of the student's skill level, objectives, contents of learning materials, and the environment. If only one method is used by the teacher in musical interpretation learning, it may not necessarily be able to achieve the learning objectives that have been determined. Therefore, the teacher uses a variety of methods in every learning process. The use of such methods can be described through an interview with vocal teacher B (Lg SMJ):

Biasanya, saya kasih contoh dulu..satu dua kali. Setelah itu siswa mencoba menyanyikan lagu seperti apa yang sudah saya contohkan. Sambil praktik, yo aku jelasi juga tentang teknik-teknik vokal, supaya mereka ngerti. (Sometimes I give one or two examples first, then the students try to sing the song like I did before. While practicing, I also explain the vocal techniques to them.) (Mtd)

The teacher's posture when giving an example using demonstration and imitation methods can be seen in Figure 10.

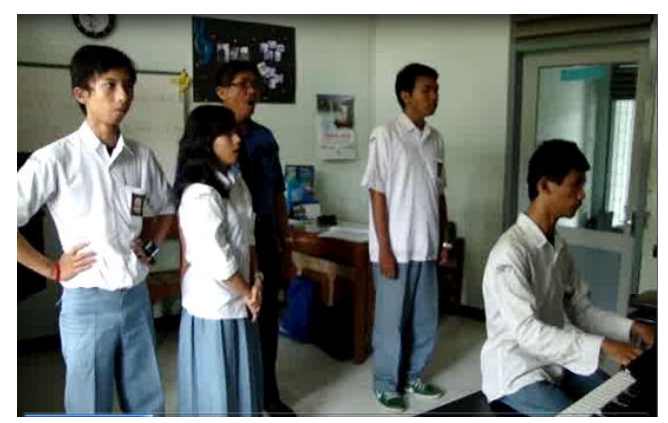

Figure 10. Vocal Teacher B Gives an Example of Correct Articulation Technique to $12^{\text {th }}$ Grade Students. (Collection: Аyи, 2012)

Based on Figure 10 and the interview with vocal teacher B (Lg SMJ), teachers use demonstration method (shows how to sing with a good and correct articulation technique) which is combined with lecture method (explaining the techniques of articulation). Teachers also use the imitation method, because teachers also give examples of singing with good and correct articulation technique. Students then try to practice singing by imitating what has been exemplified by the teacher. The use of these methods in musical interpretation learning in vocal class B is intended to motivate students to practice and continue developing their own ability and improving their singing skills.

Based on observation, we know that almost all instrument practice teachers, who are the subjects of this study, have a good personality. When teaching instrument practice, particularly musical interpretation, teachers are in a relaxed situation, including when guiding students to read musical sheets. The following interview with an $11^{\text {th }}$ grade student from saxophone class confirmed the statement above:

Pak Gmr I ngajarnya asik, santai. Ga cuma ngajarnya tapi orangnya juga asik, baik lagi. (Mr. Gmr I is a fun and relaxed person. Both his teaching and personality are admirable.) (Prsp).

Other opinions about a nice teacher also appeared on an interview with one of the $12^{\text {th }}$ grade students (Nnc) in vocal class B:

Saya senang diajar pak Lg Smj. Dia baik, sabar kalo ngajarin kita. Terus pak Lg Smj orangnya rajin. (I like being taught by Mr. Lg Smj. He's a kind person, and welltempered in class. He is also a diligent person.) (Prsp).

From those three metaphors, we can say that the teachers show an admirable personal while teaching instrument practice so that students can follow the learning process easily. Nevertheless, the teachers' nice personality is often used by students who are not prepared to practice to avoid attendance in class. In some cases, learning process have to be cancelled. This phenomenon was revealed on an interview with vocal teacher A (Yhn L.S):

Nek bocah-bocah ra siap praktek...yo wis...ora ono pelajaran. (If students are not prepared to practice, well, there will be no class that day.). (Kmpt)

The same condition happened on a piano class managed by Utr. In this class, if students are not ready enough to practice, there will be no learning process. That account is based on the following interview:

Kadang-kadang anak-anak tidak siap untuk praktik. Kalau anak-anak pada tidak siap praktik, saya tidak mengajar. 
(Sometimes students weren't prepared for practice. If they're not prepared, I can't teach them.) (Kmpt).

From what we got by the interview, it seems that although teachers have a good personality, it doesn't mean that assertiveness in class comes along with it. It is proved by seeing that there are many students who were not ready for instrument practice learning process and teachers seem not doing anything about it. Situations like this can be used by teachers to motivate their students and discuss the subject that are being taught that day.

\section{CONCLUSION}

Based on the results, the conclusion of this study is as follows:

First, in every musical instrument practice class, musical interpretation learning is not wholly taught by their teachers. It means that teachers teach musical interpretation only on its knowledge dimension, including what lies on a musical sheet. Dimensions of knowledge that are being taught include frasering, reading notes and rhythm, dynamics, tone color, and intonation, while perception dimension and realworld musical experience actually can improve and develop musical interpretation skills that were not taught nor discussed in instrument practice learning process. Most teachers tend to teach the technics of instrument performance or singing.

Second, music teachers' strategy on applying musical interpretation learning using direct learning method is a teacher-centered learning strategy with individual approach. Furthermore, teachers used imitation method in their learning process. This situation happens in every instrument practice class that are included as subjects of this study.

Third, teachers competence when teaching musical interpretation must be improved, both from their pedagogical and professional competences. From pedagogical competence standpoint, we can see that teachers only supervise students who perform music, their students were less-motivated, and teachers didn't teach musical interpretation in detail. Thus the students cannot develop many of their academic abilities. Teachers also didn't facilitate students to work out their non-academic abilities. Meanwhile, from professional competence standpoint, especially knowledge, some teachers didn't understand well the dimensions of interpretation that must be taught as well as the strategy used in musical interpretation learning.

\section{Suggestions}

Because musical interpretation is tightly related with musical performance, when teaching about any form of musical performance, teachers should teach their students to hear their own musical performance over and over again, especially when students are involved in the learning process. Based on the aforementioned suggestion, an alternative strategy about western musical interpretation learning may be applied, which is comprised of five M's. They are learning (mempelajari), seeing (melihat), hearing (mendengarkan), comparing (membandingkan), and discussing and reflecting (mendiskusikan dan merefleksikan). The flow of musical interpretation learning using $5 \mathrm{M}$ strategy is illustrated on Figure 11

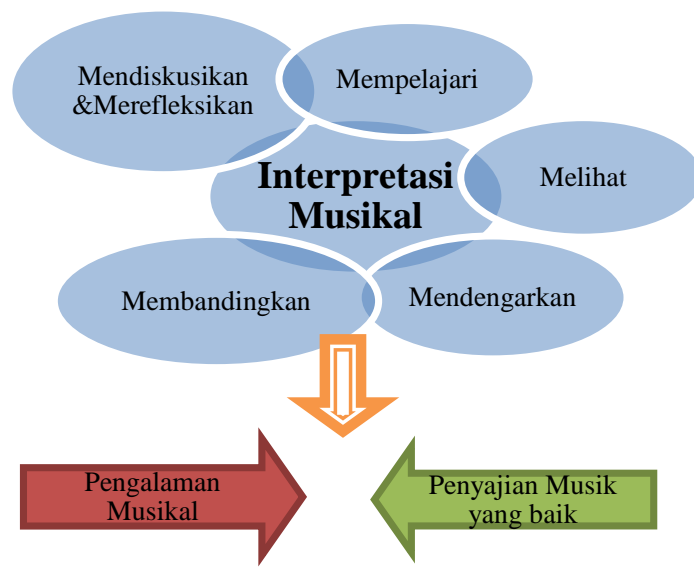

Figure 11 . . The $5 \mathrm{M}$ strategy that can be used by teachers in musical interpretation learning

Students must be more active in learning instrument practice and not dependent upon teachers in the learning process. It means that students must develop their own musical potentials, be more discipline when they indulge themselves in an independent and structured training, and keep thinking about playing western musical arts. Thus, not only they have skills to perform music, they also have an ability to interpret it well. It can be said that students are well-equipped to play musical instruments. 


\section{REFERENCES}

Abadi, M. (2011). Konsepsi "life skills" dalam sistem pendidikan Indonesia bagian 1. Retrieved February 15, 2012, from http://id.shvoong.com/socialsciences/education/2174895-konsepsilife-skills-dalam-sistem-pendidikanindonesia.pdf

Andini, N. A. (2007). Pendidikan kejuruan. Retrieved February 15, 2012, from http://www.smkn4mks.sch.id/index.php? option=com_content $\&$ view $=$ article $\& i d=$ 56:pendidikan-

kejuruan $\&$ catid $=38$ : berita\&Itemid $=63$. ht $\mathrm{ml}$

Duckworth, W. (2010). A creative approach to music fundametals, tenth edition. Boston: Macmillan Publishing.

Ford, M. (2011). Marimba: an interpretation. Retrieved January 20, 2012, from http://www.innovativepercussion.com/d ocs/documents/405/MarimbaAnInterpret ation.pdf

Gerring, J. (2007). Case study research: principles and practices. Cambridge: Cambridge University Press.

Ghozali, A. A. (2018). Kemitraan SMK Negeri 2 Kasihan Bantul. Retrieved June 6, 2018, from http://www.smmyk.sch.id/index.php/me nu/detail/16/mitra-smkn2-kasihansekolah-menengah-musik-jogja

Gillham, B. (2000). Case study research methods. London: TJ. International, Ltd.

Hermeren, G. (2001). The full voic'd quire: types of interpretation of music. In M. Krausz (Ed.), The Interpretation of Music. New York: Oxford University Press.

Kitelinger, S. (2010). Musical performance for the instrumental conductor. In Clinic from CMEA SBS Conference.

Lacey, A., \& Luff, D. (2001). Qualitative data analysis. Nottingham: Trent Focus.

Miles, M. B., \& Huberman, A. M. (1994). Qualitative data analysis: an expanded source book. Thousand Oaks: Sage Publications, Inc.

Patilima, H. (2011). Metode penelitian kualitatif. Bandung: CV. Alfabeta.

Rauner, F. (2009). Overview: TVET research. In R. Maclean \& D. Wilson (Eds.), International handbook of education for the changing world of work. London: Springer.

Reid, S. (2002). Preparing for performance. In J. Rink (Ed.), Musical performance a guide to understanding. New York: Cambridge Uniersity Press.

Silverman, M. (2007). Musical interpretation: philosophical and practical issues. International Journal of Music Education, 25(2), 101-117. https://doi.org/10.1177/02557614070799 50

Sugiyono. (2006). Metode penelitian kuantitatif kualitatif dan $R \& D$. Bandung: CV. Alfabeta.

Sugiyono. (2012). Metode penelitian kualitatif. Bandung: CV. Alfabeta.

White, J. C. (2009). Teaching musical interpretation. NACWPI Journal, Summer. Retrieved from http://www.music.cmich.edu/studies/flut e_studio/pdfs/teachingmi.pdf

Yin, R. K. (2009). Case study research design and methods (4th ed.). California: Sage Publication. 